\title{
Fish Biodiversity in the Swamp Ecosystem of Barumun River Area
}

\author{
Khairul \\ Department of Biology Education, Labuhanbatu University, Rantauprapat City, Sumatera \\ Utara Province, Indonesia
}

\begin{abstract}
Swamp flooded is a habitat of various types of fish, which as an feeding ground, shelter, and reproduction. Diversity of fish types has been utilized by the people to catch fish, as a material of consumption and economic income. One of the flooded swamp that people have utilized in the Barumun River area. The purpose of this research is to know the biodiversity of fish in the swamp flooded Barumun River. This research is explorative, with the determination of observation stations with purposive sampling methods. Fish are captured using hand cast fishing nets, fishing rods, and gill nets. Fish are identified using relevant books. Total fishing catches during the study amounted to 298 individuals consisting of 13 genera and 17 speisies. The average value of the Keanakaragaman index is 1,85 with a low cathedral. The average value of uniformity index ( $E$ ') is 0,67 in medium category. The average value of the Dominancy index (C) is 0,027 in low category. Based on the results of the study concluded the waters of Rawa Sungai Barumun has suffered disruption due to land function and pollution. This is evidenced by the Oil Palm Factory PT. Nubika Jaya and palm plantations area.
\end{abstract}

\section{Article History}

Received 15 June 2020

Accepted 1 June 2020

Keyword

Fish biodiversity, Swamp ecosystem, Barumun River.

\section{Introduction}

Swamp flooded is an area that is a habitat of various types of fish. Some types of fish make swamp flooded as areas for eating, breeding, and parenting. According to Nurdawati (2008) In his life cycle the swamp habitat flooded needed various types of fish for enlargement and for feeding. Swamp water is heavily influenced by the season, when the dry season is drought and when the rainy season floods. Utomo (2016) explains there are two groups of fish in the swamp flooded namely the group of Swamp Fish (black fish) and the river Fish Group (white fish).

The biodiversity of fish in swamped areas is potential to improve the welfare of the people. The communities around the swamp usually utilize swamp flooded to catch fish, where as a source of fulfilling nutritional needs, and some are sold for family income sources. Swamp flooded is also one type of common water that has potential freshwater fishery resources that are very important (Ditya et al., 2013). Swamp flooded in several rivers in Indonesia such as Kampar River, Musi, Lempuing, Batanghari, Rokan, Kahayan, Barito, Mahakam, and Kapuas is an ecosystem that plays an important role in the production of 
freshwater fisheries (Samita, 2001). Fish resources are essential for the balance of ecosystems, food sources, medicinal resources, and livelihood sources.

One of the undisclosed swamps of fish diversity is in the Barumun River area. The study of biodeiversity of fish is very important, because fish serves as a constituent of ecosystems, germplasm, and can be used as a bioindicator of water pollution (Ismail \& Yusof, 2011); Zulkifli et al (2012); (Wahyuni \& Zakaria, 2018). The wealth Data of comprehensive fish species in the swamp flooded Barumun River has not existed until now, so that there needs to be wealth information for the concrete species of fish to become the cornerstone of further studies, especially those related to efforts to manage fish resources in the Barumun River and its flooded swamps.

\section{Materials and Methods}

\section{Time \& Location}

This study was held in January to March 2020. Location of research in Blok 9, Sisimut Village, Kota Pinang District, Labuhan Batu Selatan Regency, Sumatera Utara Province, Indonesia. Research location map can be seen in Figure 1.

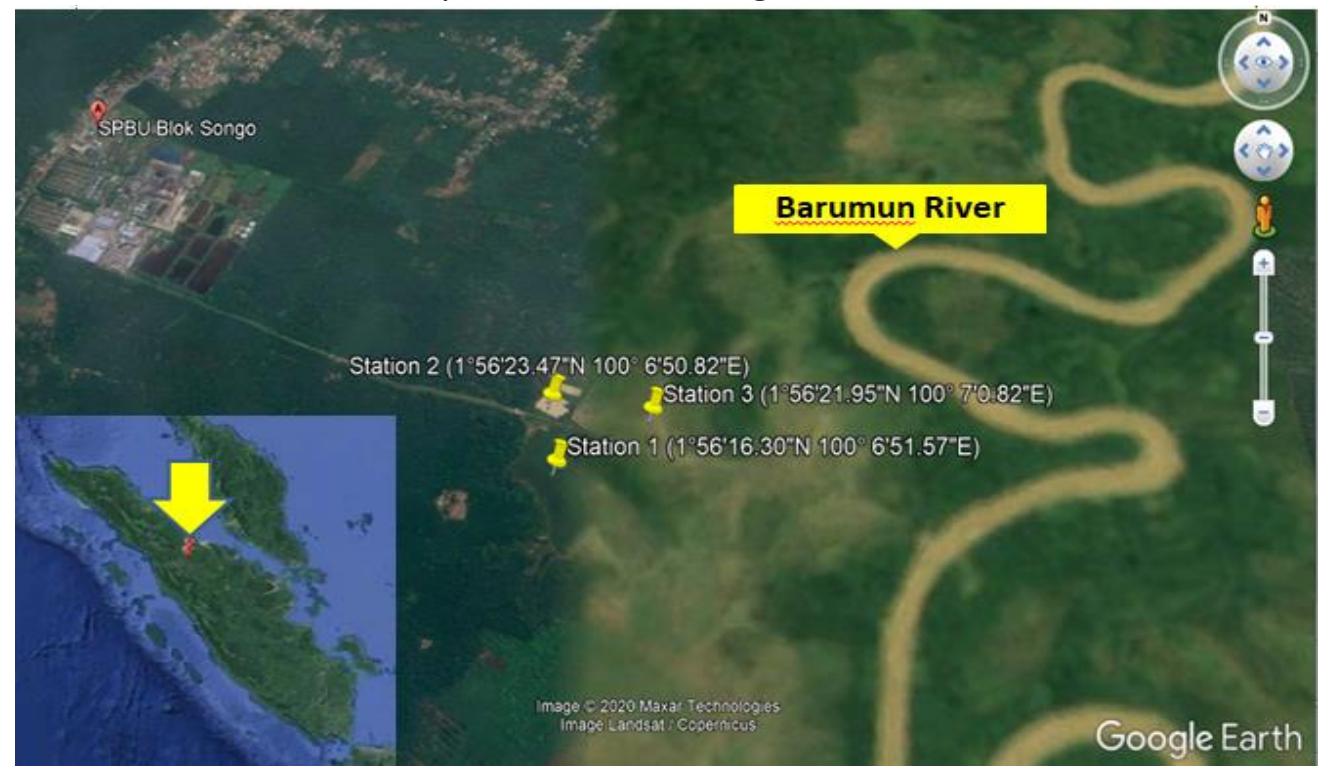

Figure 1. Map of Research Observasion

\section{Collecting Data}

This research uses the Purposive sampling method. Fish sampling using hand cast fishing nets, fishing rods, and gill nets. Caught fish are identified using the book Saanin (1984), Kottelat et al (1993), and Iqbal (2011). he tools used in this research were Global Positioning System (GPS), plot size of $50 \times 50 \mathrm{~cm}$, meter roll, sample bags, tweezers, trays, writing instruments, cameras, bivalvia identification books. The materials used are samples of Bivalves, formaldehyde, alcohol, and tissue.

\section{Analysis Data}

The Data of the research results analyzed include: Biodiversity Index $\left(\mathrm{H}^{\prime}\right)$ using formula (Krebs,1999), Uniformity Index (E'), using the formula (Magurran, 1982), and Dominance Index (C), using the formula (Odum,1991). 


\section{Results}

\section{Species Composition}

The catch of fish from the research site consists of 13 genera, 17 species, of a total of 298 individuals. The most fish caught are: Tricogester trichopterus (75 individuals), here in after followed: Brevipora ceeya (68 individuals), Helastoma temminckii (31 individuals), Oreochromis niloticus (25 individuals), Tricogester lieeri (21 individuals), Tricogester pectoralis (17 individuals), Puntius gemelus (14 individuals), Anabas testudineus (11 individuals), Aplocheilus panchax (10 individuals), Pristolepis grooti (9 individuals), Notepterus notepterus (5 individuals), Channa striata (4 individuals), Clarias betracus (3 individuals), Channa Lucius ( 2 individuals), Clarias leiachantus (1 individual), Monopterus albus (1 individual), and Pangasius pangasius (1 individual). More Data can be found in Table 1.

\section{Table 1. Species composition of fish biodiversity at the swamp of the Barumun River.}

\begin{tabular}{ccccccc}
\hline Genera & Spesies & Local Name & St. 1 & St. 2 & St. 3 & $\Sigma$ \\
\hline Anabas & Anabas testudineus & Betok/ Pirik & 6 & 2 & 3 & 11 \\
Aplocheilus & Aplocheilus panchax & KepalaTimah & 1 & 8 & 1 & 10 \\
Brevipora & Brevipora ceeya & Seluang & 2 & 64 & 2 & 68 \\
Chana & Channal ucius & Bujuk & 1 & 1 & 0 & 2 \\
Chana & Channa striata & Gabus & 2 & 1 & 1 & 4 \\
Clarias & Clarias betracus & Lele & 1 & 1 & 1 & 3 \\
Clarias & Clarias leiachantus & Lembat & 0 & 0 & 1 & 1 \\
Helastoma & Helastoma temminckii & Tambakan & 29 & 0 & 3 & 31 \\
Oreochromis & Oreochromi sniloticus & Nila & 1 & 24 & 0 & 25 \\
Monopterus & Monopterus albus & Belut & 1 & 0 & 0 & 1 \\
Notepterus & Notepterus notepterus & Putak & 1 & 2 & 2 & 5 \\
Tricogaster & Tricogester trichopterus & Sepat Rawa & 26 & 15 & 24 & 75 \\
Tricogaster & Tricogester lieeri & Sepat Mutiara & 11 & 2 & 8 & 21 \\
Tricogaster & Tricogester pectoralis & Sepat Siam & 9 & 0 & 8 & 17 \\
Pangasius & Pangasius pangasius & Patin & 0 & 1 & 0 & 1 \\
Pristolepis & Pristolepis grooti & Sipatung & 7 & 1 & 1 & 9 \\
Puntius & Puntius gemelus & Kemuringan & 2 & 10 & 2 & 14 \\
\hline
\end{tabular}

\section{Ecological Index}

The observed ecological indices include: Diversity Index $\left(H^{\prime}\right)$ at the Station $1(1,98)$, Station $2(1,65)$, and Station 3 (1,93). Uniformity Index (E'), Station $1(0,710$, Station $2(0,60)$, and Station $3(0,69)$. Dominancy Index $(C)$, Station $1(0,02)$, Station $2(0,02)$, and Station 3 $(0,04)$. The results of an ecological index analysis are shown in Table 2. 
Table 2. Average value of the ecological index of fish biodiversity at the swamp of the Barumun River.

\section{Ecological Index}

\begin{tabular}{ccccccc}
\hline Station & H'$^{\prime}$ & Category & E'$^{\prime}$ & Category & $\mathbf{C}$ & Category \\
\hline 1 & 1,98 & Low & 0,71 & Medium & 0,02 & Low \\
2 & 1,65 & Low & 0,60 & Medium & 0,02 & Low \\
3 & 1,93 & Low & 0,70 & Medium & 0,04 & Low \\
\multirow{2}{*}{ Averange } & $\mathbf{1 , 8 5}$ & Low & $\mathbf{0 , 6 7}$ & Medium & $\mathbf{0 , 0 2 7}$ & Low \\
\hline
\end{tabular}

\section{Discussion}

Types of fish that are caught in the swamp flooded River Barumun is Tricogester trichopterus (75 individuals), belonging to the family Osphronemidae. The Osphronemidae family is a type of fish that has a maze. The maze of fish is as a form of morphological adaptation, where fish as organisms living in marshes have the ability to adapt to low $\mathrm{pH}$ and oxygen. Certain types of fish that can use oxygen from the free air, have more durability over dissolved oxygen-deprived waters (Wardoyo, 1978). The results of the research of Asyari (2006) in Rawa Muning gained 13 types of fish dominated by black fish such as: Trichogaster trichopterus, Anabas testudineus, and Channa striata. Gunawan \& Jumadi (2016) in his research to obtain the most fish catches is Trichogaster trichopterus 77 individuals. Next is the Brevipora Ceeya species (65 individuals) belonging to the family Cyprinidae. The family of the Cyprinidae are the dominant fish found in the flooded swamp area. According to Simanjuntak et al (2007); Kottelat et al (1993), Family Cyprinidae are the world's largest freshwater fish species and are capable of living in a variety of habitats. Fish that live in swamp forest are generally types that are resistant to changing water quality (Nurdawati \& Prasetyo, 2007). According to Marini \& Husna (2010), The Cyprinidae family is the most common group of fishes found in freshwater and some of these family can survive in degraded environments. The degradation of swamp ecosystem because land clearing and convertion of lands from naturally tobe agriculture as plantation and other usage (Sagala, 2015).

The diversity index $\left(\mathrm{H}^{\prime}\right)$ value of the three stations indicates a medium category. Based on the criteria of the index value of the diversity of Shannon Wiener, if $\mathrm{H}^{\prime} \leq 3,32$ then the diversity is relatively low. The low diversity index value indicates that the ecosystem is experiencing reduced pressure or condition. According to Gunawan \& Jumadi (2016) low fish biodiversity indicates habitat conditions that have been damaged, for example: habitat degradation, natural disasters, pollution, and others. The Uniformity Index ( $\left.E^{\prime}\right)$ values obtained ranged from $0.4<\mathrm{E} \leq 0.6$, so the Uniformity Index is categorized as moderate, meaning that the community is unstable. Dhahiyat et al (2003) states that the condition of community structures that are in an unstable state indicates ecological pressure. The results of the research Dominance Index indicates a value of $0<\mathrm{C} \leq 0.5$, with low dominancy criteria. This means that there is not a type of fish that dominates in the swamp area flooded with Barumun River. Suspected capture equipment to catch fish on some less effective stations, so the fish is not much to be caught. According to Nugroho et al (2015), the selectivity of the capture tool determines the value of the dominancy. 


\section{Conclusions}

Types of fish caught dominated by family Osphronemidae and Cyprinidae, considering that this fish is a highly adaptable group in the swamp ecosystem. In addition, it is suspected that the swamp ecosystem is a suitable place for feeding, clusters, and shelter for the fishes. Sustainability as a habitat of fish needs to be maintained so that the diversity of fish becomes abundant, so it can be utilized by the surrounding community.

\section{References}

Asyari. 2006. Karakteristik Habitat dan Jenis Ikan pada Beberapa Suaka Perikanan Di Daerah Aliran Sungai Barito, Kalimantan Selatan. Jurnal IImu-ilmu Perairan dan Perikanan Indonesia, 13(2), 155-163.

Dhahiyat, Y., Sinuhaji, D., \& Hamdani, H. 2003. Struktur Komunitas Ikan Karang di Daerah Transplantasi Karang Pulau Pari, Kepulauan Seribu. Jurnal Iktiologi Indonesia, 3(2), 87 94.

Ditya, Y. C., Rais, A. H., Syarifah, N., \& Wiadnyana, N. N. 2013. Peranan Lebung Sebagai Sumber Ekonomi Bagi Nelayan Dan Sarana Pengelolaan Sumber Daya Ikan Rawa banjiran Di Sumatera Selatan. Jurnal Sosial Ekonomi Kelautan dan Perikanan, 8(1), 3947.

Iqbal, M. 2011. Ikan-ikan Di Hutan Rawa Gambut Merang Kepayang dan Sekitarnya. Palembang: Merang REDD Pilot Project.

Ismail, A., \& Yusof, S. 2011. Effect of Mercury and Cadmium on Early Life Stages of Java Medaka (Oryzias javanicus): A potential tropical test fish. Marine Pollution Bulletin, 63, 347-349.

Kottelat, M., Whitten, A. J., Kartikasari, S. N., \& Wirjoatmodjo, S. 1993. Freshwater Fish of Western Indonesian \& Sulawesi. Hongkong: Periplus Editions.

Krebs, C. J. (1985). Ecology The Experimental Analysis of Distribution and Abundance. New York: Harper \& Row Publisher.

Magurran, A. 1988. Ecological Diversity and Its Measurement. New Jersey: Princeton University Press.

Marini, M., \& Husnah. 2010. Struktur Komunitas Ikan Dalam Hubungannya Dengan Kualitas Air Bagian Hilir Sungai Siak, Provinsi Riau. Prosiding Seminar Nasional Limnologi V tahun 2010 (pp. 156 - 173). Bogor: Lembaga Ilmu Pengetahuan Indonesia.

Nugroho, H. A., Rosyid, A., \& Fitri, A. D. 2015. Analysis of Diversity Index, Domination Index and Non Target Catch Proportion Modified Arad in Kabupaten Kendal Waters. Journal of Fisheries Resources Utilization Management and Technology, 4(1), 1-11.

Nurdawati, S. 2008. Fauna Ikan di Perairan Rawa Banjiran Sungai Batanghari, Jambi. Prosiding Seminar Nasional Ikan V, (pp. 65-76). Bogor.

Nurdawati, S., \& Prasetyo , D. 2007. Fauna Ikan Ekosistem Hutan Rawa DI Sumatera Selatan. Jurnal Iktiologi Indonesia, 7(1), 1-8.

Odum, E. P. 1991. Fundamentals of ecology (Third eddition ed.). Philadelphia: W. B. Saunders Co.

Saanin, H. 1984. Taksonomi dan Kunci Identifikasi Ikan. Bandung: Binacipta. 
Sagala, E. P. 2015. The Biodiversity of Nursery Ground in Swamp Areas Important to Survive The Black Fishes in The Wetland. Biovalentia, 1(1), 34-38.

Samita, A. S. 200. Potensi dan tingkat pemanfaatan perikanan perairan umum sekitar lahan persawahan pasang surut Sumatera Selatan. Jurnal Penelitian Perikanan Indonesia, 7(2), 1-11.

Simanjuntak, C. P., Rahardjo, M. F., \& Sukimin, S. 2007. Iktiofauna Rawa Banjiran Sungai Kampar Kiri. Jurnal Iktiologi Indonesia, 6(2), 99-109.

Utomo, A. D. (2016). Strategi Pegelolaan Suaka Perikanan Rawa Banjiran di Sumatra dan Kalimantan. Jurnal Kebijakan Perikanan Indonesia, 8(1), 13-20.

Wahyuni, T. T., \& Zakaria, A. 2018. Keanekaragaman Ikan di Sungai Luk Ulo Kabupaten Kebumen. Biosfera, 35(1), 23-28.

Wardoyo, S. T. H. 1978. Kriteria Kualitas Air Untuk Keperluan Pertanian dan Perikanan . Prosiding Seminar Pengendalian Pencemaran Air (pp. 293-300). Jakarta: Direktorat Jenderal Pengairan, Departemen Pekerjaan Umum.

Zulkifli , S. Z., Yusuff , F. M., Ismail, A., \& Miyazaki, N. 2012. Food Preference of the Giant Mudskipper Periophthalmodon schlosseri (Teleostei: Gobiidae). Knowledge and Management of Aquatic Ecosystems, 405(07), 1-10. 